$12-31-2018$

\title{
Planning green patch: towards an ecological place of Ciliwung Condet
}

\author{
Rini Suryantini \\ Universitas Indonesia, rinisuryantini@gmail.com \\ Galavia Permata \\ Universitas Indonesia
}

See next page for additional authors

Follow this and additional works at: https://scholarhub.ui.ac.id/ajce

Part of the Social and Behavioral Sciences Commons

\section{Recommended Citation}

Suryantini, Rini; Permata, Galavia; and Angelia, Dini Puti (2018). Planning green patch: towards an ecological place of Ciliwung Condet. ASEAN Journal of Community Engagement, 2(2).

Available at: https://doi.org/10.7454/ajce.v2i2.138

Creative Commons License

(c) (i) ()

This work is licensed under a Creative Commons Attribution-Share Alike 4.0 License.

This Research Article is brought to you for free and open access by the Universitas Indonesia at ASEAN Journal of Community Engagement. It has been accepted for inclusion in ASEAN Journal of Community Engagement. 


\title{
Planning green patch: toward an ecological place of Ciliwung
}

\section{Condet}

\author{
Rini Suryantinia ${ }^{*}$, Galavia Permataa, Dini Putri Angelia ${ }^{a}$ \\ a Universitas Indonesia
}

Received: November 28, 2018 || Revised: November $7^{\text {th }}$ and 28, 2018 || Accepted: December $30^{\text {th }}, 2018$

\begin{abstract}
This paper illustrates a program to plan a green patch of Ciliwung river landscape through a participatory process involving the community in Condet, East Jakarta. It is believed that native knowledge of the river and the riparian, which can only be revealed by the locals, becomes significant to understanding the dynamics of the place and to generating a masterplan. Through interviews, focus group discussion and participatory mapping, their everyday experience in utilizing the landscape can be recognized. Instead of concrete revetment and heightened levees along the river, native vegetation is identified and developed, as it is considered as key in restoring the ecosystem and generating programs on the landscape. The landscape will display the natural process and at the same time provide a place for social and recreational activities. By utilizing the native knowledge of the people, the masterplan of the green patch becomes more responsive and fit to the ecological, cultural, and social research. Fostering the commitment and active role of the community in every phase of the planning turns into an important aspect to ensuring the implementation and sustainability of the program. This program will support the aim of the community and will strengthen the identity of Condet as a site for ecology, and will eventually support the conservation program in Ciliwung Condet.
\end{abstract}

Keywords: masterplan; landscape improvement; native vegetation; ecology; participatory; Ciliwung Condet.

\section{Introduction}

Water is a central element of life and should be managed wisely as part of urbanism. Involvement of more stakeholders especially in developing science and technology of water management is crucial. This involves identifying innovative solutions that protect public health; secure supply, flood control, and mitigation; and at the same time ensure environmental conservation and resources efficiency (Farrelly and Brown, 2011: 731). Marlow et.al. (2013: 7157) suggested the current model of urban water service needs a change to become a more sustainable urban water model that allows diverse technology development.

In the last decade, Jakarta places the river mainly as the urban drainage system, developing and maintaining it using a top-down approach. This seems to fail recognizing

*Correspondence Author: rinisuryantini@gmail.com 
the river as an important element in the urban setting and rather separate it from the rest of the city. This paradigm also takes the river for granted and places this dynamic ecosystem in the backseat. The impermeable cover and elevated embankment of the river landscape, as well as rapid increase in land use, such as human settlement along the river, decreases the green space, disrupts the water cycle, and degrades the ecological function of the river.

Reflecting on the ecological condition of the river and river landscape, as well other important functions of the river, restoring the ecological function of the landscape with the participation of the community has an attempt to improve the surroundings of the river. This paper discusses the importance of developing an ecological green patch as part of urban watershed area and illustrates the importance of participation of the locals in the planning process.

\subsection{Community in the Ciliwung}

As one of the 13 rivers that run through Jakarta, Ciliwung river stretches to more than $117 \mathrm{~km}$ long from the upstream on the mountain in West Java until the Java Sea (Ali et al., 2016:52). The river can be divided into three zones based on its topo-sequence, and Jakarta has the middle and downstream part of Ciliwung (Aini, et al., 2018:223; Ali et al., 2016:52). The river plays an important role in supplying freshwater for the urban Jakarta reservoir, in transportation, and in providing a place for recreation, and education, and green space.

As part of the watershed ecosystem, the river and riverside in Indonesia are maintained as a drainage system by the government, all of which can vary in condition. This paradigm is focused on the Ciliwung river, which serves as the main drainage system of Jakarta (Diyanti, et al., 2017). The rapid development of the area followed by inconsistent land use upstream and along the river (Aini, et. al., 2018: 223; Ali, et.al., 2016:52; Arifasihati \& Kaswanto, 2016:467), pollution, aesthetic enhancement and river restoration on the downstream (Diyanti, et.al. 2017), as well as a rigid concrete embankment as urban drainage system and flood prevention (Padawani \& Douglass, 2015: 528), has put the river ecosystem in chaos. These interventions are most of the time seen as a top-down approach. This technical intervention aims to prevent floods during rainy season, it cannot secure the water supply during dry season (Asun, 2018). This 
Rini Suryantini, Galavia Permata, Dini Putri Angelia| ASEAN Journal of Community Engagement | Volume 2, Number 2, 2018

contrasting situation every year shows that the intervention interrupts the flow of the water, affecting the wellbeing of the urban inhabitants.

a

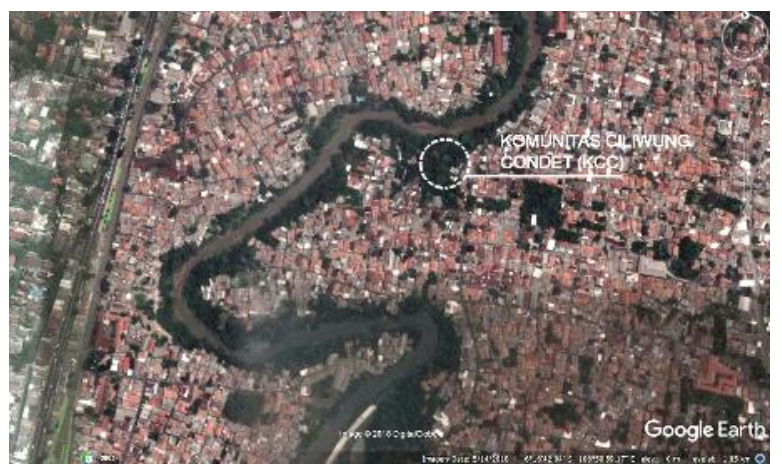

$\mathrm{b}$

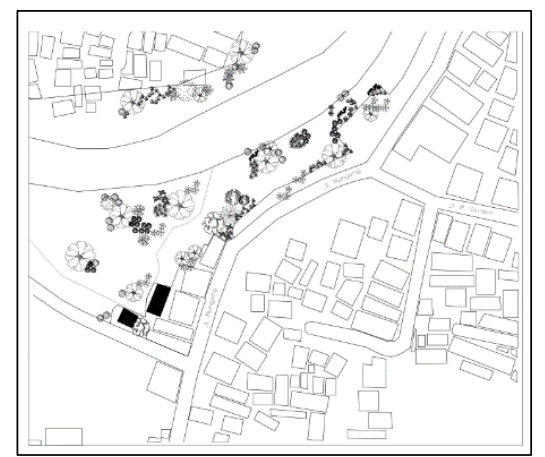

Fig 1. (a) Ciliwung River through Pasar Minggu and Condet area; (b) Block plan of Komunitas Ciliwung Condet base camp and surroundings Source: Google Earth, accessed October 2018 (edited); Author (2018)

There are more than 20 communities along Ciliwung river upstream and downstream Jakarta Bay; these are communities that share the same passion for nature and river conservation (Padawangi \& Douglass, 2015:537-538; Tampi, Sumabrata, \& Darmajanti, 2018). The Komunitas Ciliwung Condet (KCC) is one of the active nature enthusiasts that reside by the Ciliwung river. As part of the river-conservation network, KCC connects with other river communities and is supported by volunteers, students, small enterprises, local residents, and other participants. As residents, KCC observes the shift in the river course, plants different riparian vegetation, builds docks by the river, keeps the river clean from solid waste, grows salak fruit, and other activities (Abdulkadir, 2018). They invite the public to engage in these activities to promote a connection between the river and the land community members. The land area is more than 3,000 sqm, occupying the downstream area of Ciliwung (Fig 1) and providing an open space (Fig 2). KCC conserves this patch of land as water catchment and intends to develop it to become an eco-tourism area (Abdulkadir, 2018). 


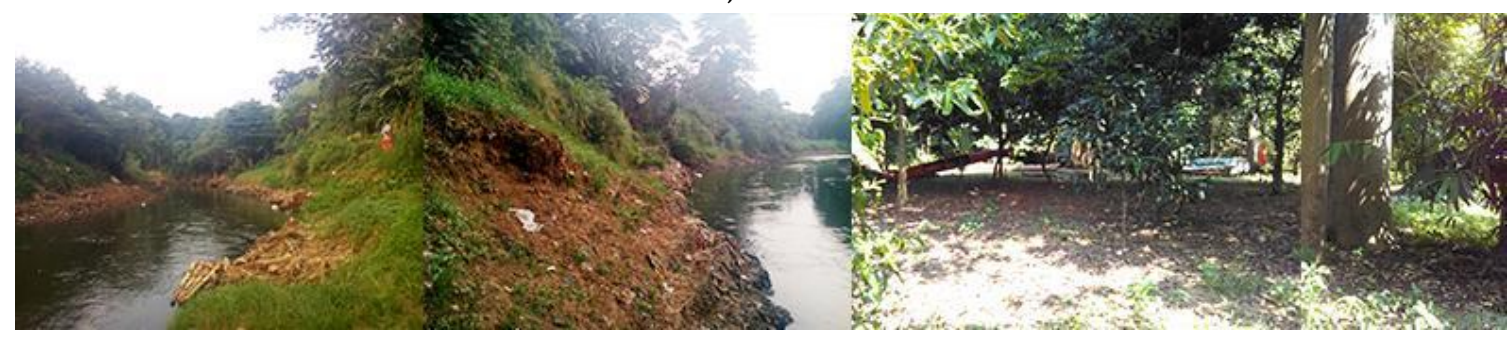

Fig 2. The condition of Ciliwung river and its riverbank

Source: Author, 2018

A Betawi cultural conservation area and central area of fruits in Jakarta, Condet faces an inevitable rapid development. The Ciliwung river is hardly recognized and has become more distant from the people. This threatens the existence of the river and the green open space along with its biodiversity, including the land preserved by KCC. Aggravated by the development of concrete infrastructure by the Ciliwung river, KCC tries to find a way to negotiate with the government to maintain the land as green area. This shows the important of the role of the community in sustaining the environment and protecting the Ciliwung river landscape.

\subsection{Planning a sustainable landscape through participatory}

Landscape needs to be perceived as a system, that consists of entities and relationship, as a function through interrelated of parts, and at the same time exhibit properties of independent parts (Motloch, 2000: 1-2). This perspective is appropriate to studying living organism, since organisms interact with their surroundings (Herrington, 2017: 222-223). It is important to understand that landscape as a system, because it considers process and provide comprehensive understanding to the changes. The landscape experiences constant change, which is greatly influenced by humans either through cultural, technical, or ecological process. As the condition of a landscape rapidly degrades, the landscape becomes more dissipative, resulting in negative feedback, conflict, and stresses and eventually affecting the residents and other parts of the landscape (Motloch, 2000:1-2). To prevent further damage, there is a need to plan its design and management.

A method for examining the behavior of the ecosystem on a landscape is developed by Richard T.T. Forman. This examines the structure and performance of landscape based on the "patch" or "corridor" (Livesey, 2015, p. 229). A patch of landscape is defined as a 
Rini Suryantini, Galavia Permata, Dini Putri Angelia| ASEAN Journal of Community Engagement | Volume 2, Number 2, 2018

territory or space that has specific composition, shape, size, edge characteristics, and adjacencies, which are activated by the population of its inhabitants. The term patch becomes relevant for Ciliwung Condet, since the plot of land is arranged internally and at the same time relates to a larger context, the river and the urban area. The arrangement of landscape elements and how they are connected and changed will be key to the development of the landscape.

The landscape infrastructure is a network of physical and biophysical systems that facilitate the necessary operation of daily life (Herrington, 2017:232). It transports water, water, and other materials from one location to another. In the past, it was seen passively, but now it has evolved into an active part of the ecosystem that is contributing to the technology and aesthetic development in the area. Many terms are developed in the previous decades to illustrate new approaches that are sustainable, holistic, and integrated.

Nowadays managing stormwater runoff and its impact on urban communities involves a wide range of issues including that of the environment, sanitation, society, and economics (Public Utilities Board Singapore, 2018; Fletcher, et al., 2015). Water infrastructure varies in terms of technology application and considerations on the ecosystem. A water sensitive model is used to regulate water consumption for a more sustainable environment (Abd El Aziz, 2016). This model includes water management and urban and landscape design, in which it tries to decrease pollution and flood risk, protect water supply and the wellbeing of the community, and increase river and riparian biodiversity. This model involves several methods for the urban and landscape design; of which two are through land and soil improvement, hardscape and planting, mulch and water feature, which eventually preserve water quality and reduce stormwater runoff. This model is very suitable for river and river landscape restoration.

If a river landscape is to be improved and restored, a clear goal is required. A specific goal will determine the priorities to be set, suitable approaches to be considered, scenarios to be developed, and results to be assessed (Gonzales, et al., 2015; Kondolf, Boulton, O'Daniel, \& Poole, 2006; Palmer, et. al., 2005). There are four common approaches frequently used in restoring and improving the river ecosystem: hydrogeomorphic treatment, active plant introduction, exotic species control, natural floodplain conversion, and grazing and herbivory control (Gonzales, et al., 2015), especially for local scale (meander). 
The hydrologic and geomorphic features are intervened by land. Hydrogeomorphic treatment means the recreation of hydrologic and/or geomorphic condition of the watershed area to improve its function; this type of treatment can be active or passive. Detention basin, bioretention or rain garden, bioretention swale, permeable paving, green roofs, constructed wetlands, sedimentation basin, vegetated swale, and cleansing biotopes are the alternatives of stormwater intervention (Patchett \& Price in Farr, 2008:178). They are suitable for landscape improvement that deals with less invasive and rigid technology to the hydrologic and geomorphologic condition of the watershed area.

Aside from hydrogeomorphic treatment, the role of vegetation, especially native vegetation, is highlighted. The vegetation is crucial for stormwater intervention and riverbank ecosystem improvement. Not only is native vegetation proven to safeguard the ecosystem, but also it provides opportunities for the landscape to be restored (Gonzales, et al., 2015). Native vegetation is proven well-adapted the local condition (Abd El Aziz, 2016), In this case, the surface water level varies periodically, with a possibility of changes in the water table as well. Some types of vegetation have strong roots, which help in floodwater absorption and keeping the elevated land surface intact. Native vegetation can be an indicator of the type of ecosystem and changes in the ecosystem, either improvement or degradation. Employing native vegetation in the method is simple yet effective, especially for water filtration, nutrients regeneration, and channeling floodplain, which can also be combined with other approaches (Gonzales, et al., 2015; Palmer, et al., 2005). To restore the function of watershed landscape and prevent disconnection of land surface and water, considering native vegetation is recommended.

To design a meaningful landscape, one must understand the factors that influence its form and be sensitive to their meaning (Motloch, 2000: 3). Some landscapes are difficult to comprehend, since they evolve in response to the factors that influence their change over time. These factors include activities that have sociocultural, social, technical, and ecological aspects (Kondolf, et. al., 2006). A good responsive landscape can be generated by revealing its meaning.

Participatory design is an approach that tries to engage everyone in the process to ensure the designed product or service or transformation of the environment meets the needs of the user (Sinha, 2012: 175). This approach is believed to be responsive, appropriate, and effective. Knowledge and understanding of the siter are important to start a participatory design (Hester, 2006:369-370). As an observer, non-natives are 
Rini Suryantini, Galavia Permata, Dini Putri Angelia| ASEAN Journal of Community Engagement | Volume 2, Number 2,2018

separated from the natives. Relying solely on the field observation will not result in a comprehensive understanding of the place and its dynamics due to a lack of grounding in the fundamental principles of the ecosystem, which can be seasonal, annual, or episodic (Hester, 2006:328-330). A comprehensive knowledge can be only obtained from the natives' direct experience through living and livelihood. This shows the vital role of community participation in the design process, in which the meaning of influential forces in the landscape can be better encapsulated and represented.

A masterplan is aspired by the community to create a landscape that offers a possible connection between the nature and people through educational, social, and recreational programs for a sustainable environment. By means of community participation, understanding the landscape as a system can provide a comprehensive masterplan. The ecological perspective on the landscape is better revealed through the knowledge on the native vegetation of the community. By looking at the native vegetation and engaging in community discussion on the suitable technological approach, a thorough and meaningful Ciliwung Condet landscape can be planned and a proposal drafted.

\section{Methods}

As a participatory program in planning the landscape of Ciliwung Condet, this project collaborates with the KCC and this is conducted at the KCC base camp on Jalan Munggang, Balekambang, Condet, East Jakarta. The participatory activities involve two main phases: (1) participatory data collection and (2) development of ideas ad programs.

\subsection{Participatory data collection - place knowing and understanding}

Data collection is part of getting to know the place and understand it, which is important for the planner, and a participatory data collection is required to complete the puzzle. To get a comprehension of the place, more information should be acquired, and this is where the community participation becomes beneficial in the planning process.

The study of the site is conducted through a series of activities, starting from making an inventory, mapping and studying the landscape first-hand through checking water quality and measurement, and documenting habitat through photos and sketches (Fig 3). The data collecting process takes place four times from June until August 2018 at the residence of a KCC member at Jalan Munggang, Condet. The study involves close, detailed 
Rini Suryantini, Galavia Permata, Dini Putri Angelia| ASEAN Journal of Community Engagement | Volume 2, Number 2,2018

observation to discover the natural landscape. The contour and other landscape features, especially native vegetation that is important to river ecology, economic activity, social activity, and domestic use, are identified, observed, and mapped in detail. This participatory mapping includes photographic instrument, which reveals not only the local habitual or cultural events, details of surfaces, layers of activity, the subjective layers (e.g., place attachment), but also the spatial relation (Warner, 2015: 2-3).

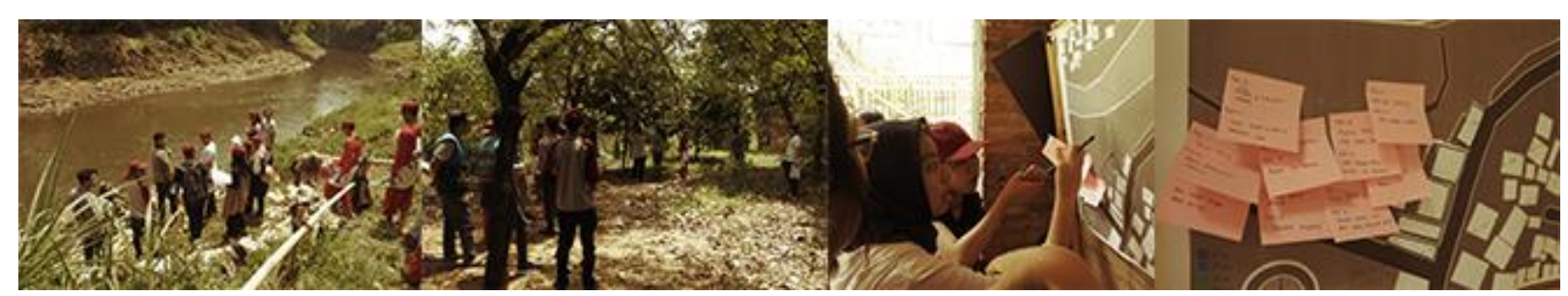

Fig 3. The river and landscape mapping workshop Source: Author, 2018

Through the workshop, that involve 40 participants from local youth organization members, information is compiled to generate comprehensive maps of the landscape. The maps are complemented by in-depth interviews and group discussion with residents, the chief of KCC, the core team of KCC, two local government representatives, and a group of housewives. In-depth discussions are conducted with individuals or within groups using open-ended questions to identify current issues, the livelihood, and everyday living. This process is part of the process of place knowing or understanding, in which certain patterns of activities, especially related to native vegetation, and their relation to the landscape, are recognized.

\subsection{Development of ideas and programs - place caring and preparing action}

As data are gathered and analyzed, place caring and action are the next steps, which include developing a concept (Hester, 2006:370). It is about getting a gestalt or form and developing the range of plans and programs, marking the landscape, and making layouts based on the previous phase's result. The community plays big role in the development of ideas and programs, in which they utter previous and possible activities on site, express their concern on environmental loss, and identify native vegetation, and also the difficulties in managing the site (Fig 4). Although everybody is encouraged to participate 
Rini Suryantini, Galavia Permata, Dini Putri Angelia| ASEAN Journal of Community Engagement | Volume 2, Number 2,2018

and engage equally in the process, in reality, some participants are afraid or reluctant to participate in the design process. Therefore, to facilitate the process of design, an expert facilitator is required in the case (Sinha, 2012:184). The expert, such as an architect whose expertise is on landscape design, is to contribute in this part of the design process and guide architecture students. The proposed masterplan will be used as a recommendation for KCC to develop further their program, to promote the landscape as a hub where people and nature interact.

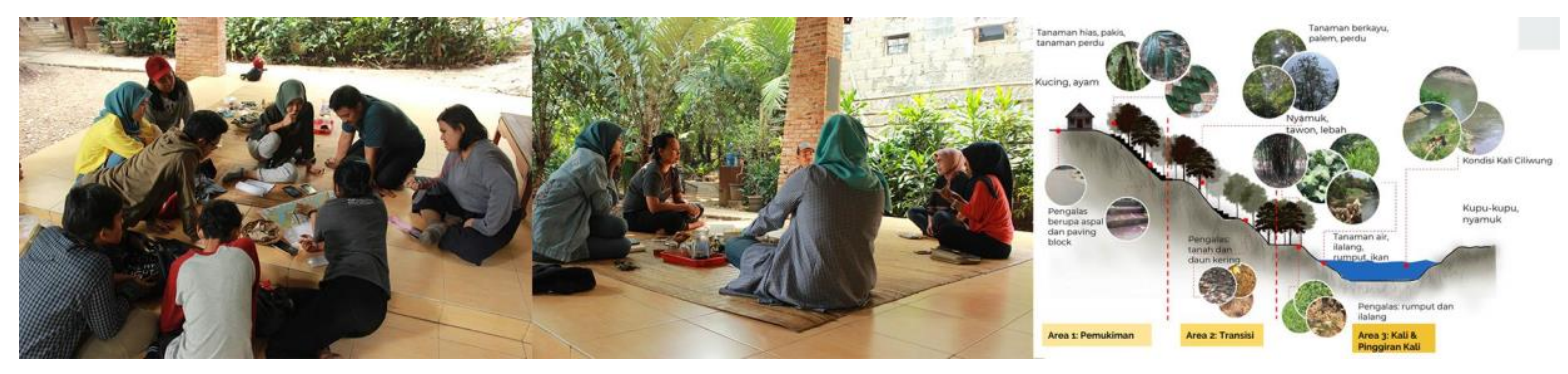

Fig 4. Workshop in developing layouts, plans, and programs

Source: Author, 2018

\section{Result and Discussion: Planning Ciliwung Condet green patch}

Located in a challenging landscape, KCC developed the landscape themselves. Based on the terrain, three zones of the landscape can be identified high plain, intermediate plain, and low plain (Fig 5). As a community that aims for eco-tourism destination, they realized the landscape arrangement needs to be improved, especially to respond to the government's program to build an inspection road along the river as well as concrete revetment.
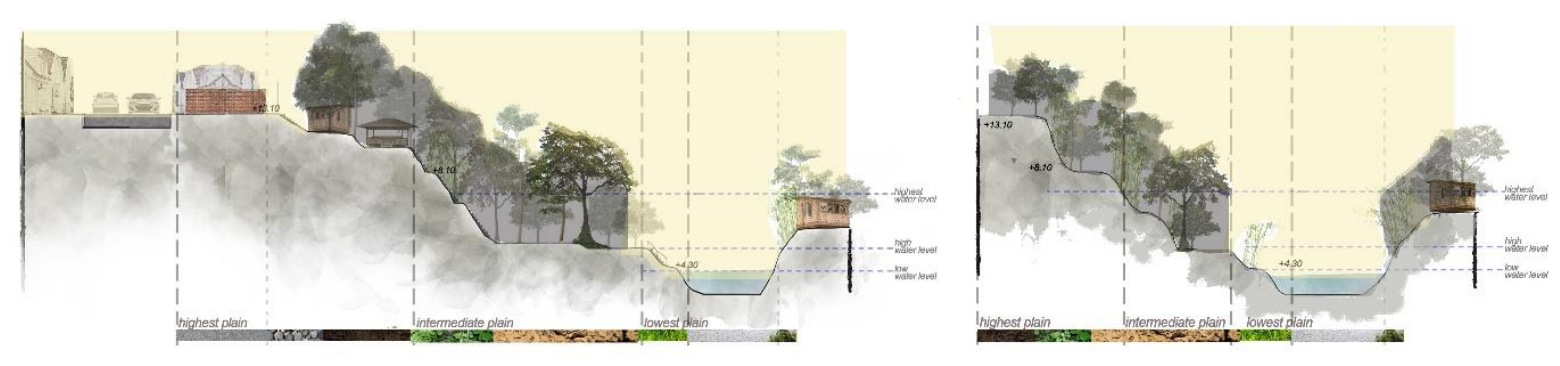

Fig 5. Landscape profile of KCC base camp

Source: Author, 2018 


\subsection{Identifying the green patch}

A map is developed based on the participatory-design mapping, interviews, and discussion. It shows the landforms water bodies, vegetation, and traces of human activities. The documented everyday occurrences on Ciliwung Condet landscape serves as basis for further development (Fig 6). Based on the maps' development, important points are revealed. Vegetation, which has a crucial role in the ecosystem and from the sociocultural perspective, grows in the landscape on certain pattern. The strength of the landscape is on the large area of land surface, its steep contour, and presence of native vegetation, and its areas to improve includes its limited access for maintenance of the riverbank and unprotected riverbank.
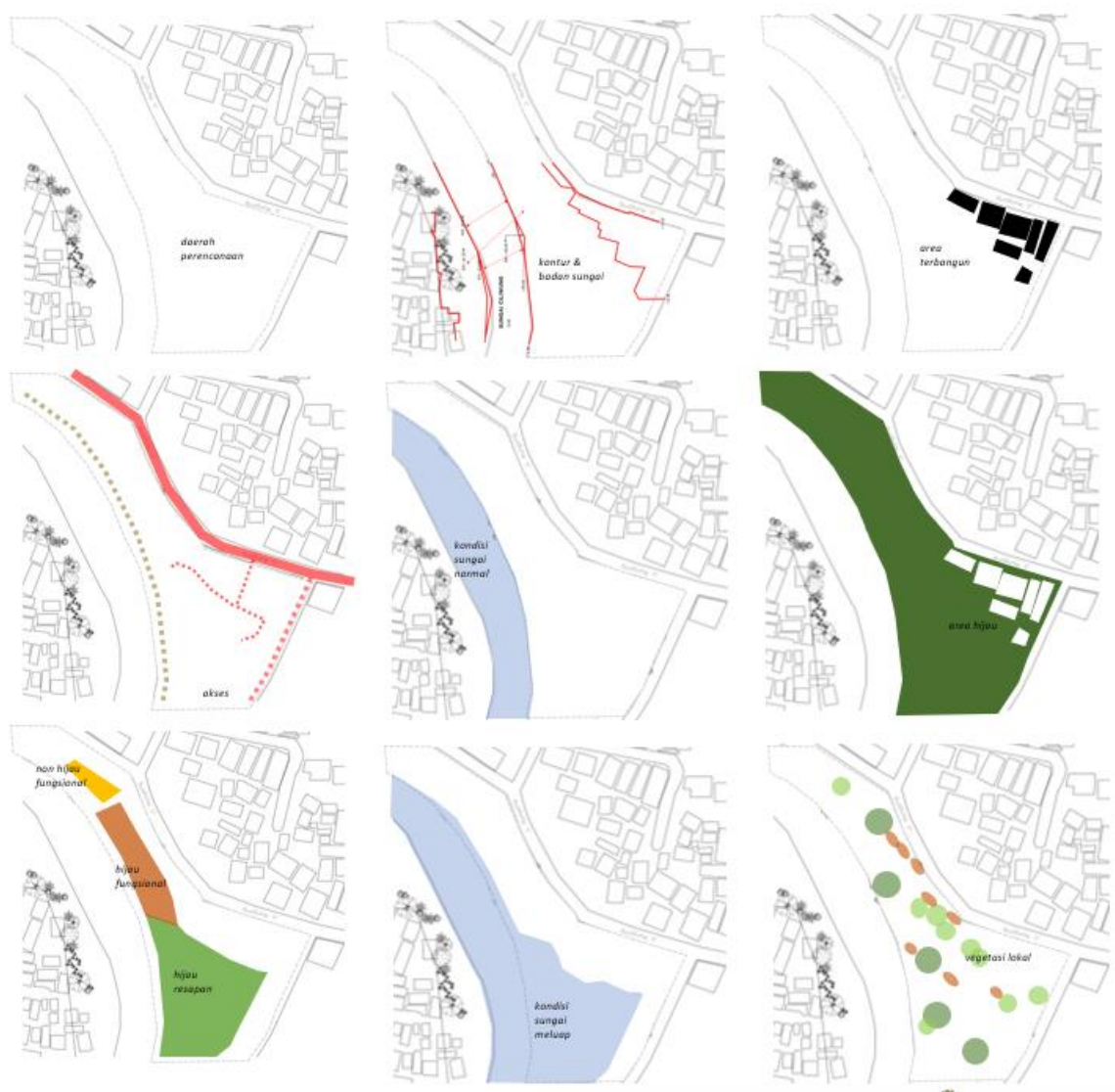

Fig 6. Layers of information of KCC landscape

Source: Author, 2018

The high plain has direct access to the street and acts as the main area and base camp. There are two units of structure: a gazebo-like structure, which can be used for recreational activities, and a glass-house structure, which can be used for meetings or a 
Rini Suryantini, Galavia Permata, Dini Putri Angelia| ASEAN Journal of Community Engagement | Volume 2, Number 2,2018

library or a prayer room. There is also a toilet and a pantry. Due to the challenging landscape and minimal developments at the site, it is experiencing difficulties in supporting community activities due to concerns regarding accessibility, convenience, and safety.

The plain is located in an elevated area and arranged to be an outdoor seating area, mainly a place for viewing the scenery and witnessing the plucking of salak (Salacca zalacca) or snake fruit, the native fruit of Condet. Vegetation in this area includes shrubs, trees with a height of more than six meters, and large canopies, such as picung tree (Pangium edule) and gandaria tree (Bouea macrophylla Griffith). The large trees and the structures at the site serve as the shade for the visitors.

There is an open ground on the second plain that has vegetation, including kapuk randu tree (Ceiba pentandra L. Gaertn), salak tree (Salacca zalacca), bamboos (Bambuseae), rambutan tree (Naphelium lappaceum), gandaria tree (Bouea macrophylla Griffith), petai cina tree (Leucaena leucocephala), and small shrubs. However, this open ground can fill with water when the river overflows during rainy season. The trees cover only half of the open ground area, and the best hours this area can be used are in the mornings and the evenings. Humidity is also relatively high due to vegetation surrounding it and its location of being near the river. Therefore, the open ground should be utilized for some active or passive outdoor activities.

The lowest part of the landscape is an area nearest the river. It receives the most sunlight during the day, being only partly shaded in the early morning and late evening. The low pain has high temperature and high humidity, and ventilation can only be experienced from the prevailing wind upstream or downstream. Vegetation in the area include bamboos (Bambuseae), small shrubs, such as talas (Araceae), banana tree (Musaceae), katuk (Sauropus androgynus) and wild groundcover, such as alang-alang (Imperata Cylindrica), kencur (Kaempferia galanga), and trees, such as kapuk randu (Ceiba pentandra L. Gaertn) and gandaria (Bouea macrophylla Griffith). This area is also where animal species can be observed, including fishes, plecos, snails, butterflies, and dragonflies. The community at present use this area for active sports, such as rafting, hiking, and biking. During rainy season, this area can be flooded with water. 
Rini Suryantini, Galavia Permata, Dini Putri Angelia| ASEAN Journal of Community Engagement | Volume 2, Number 2, 2018

Table 1. Prevalent vegetation in Ciliwung Condet

\begin{tabular}{|c|c|c|c|c|}
\hline Zone & Species & Function / Role & Habitat & $\begin{array}{l}\text { Related } \\
\text { Animal/ } \\
\text { Insects }\end{array}$ \\
\hline \multirow{5}{*}{$\begin{array}{l}\text { Highest plain } \\
\text { And } \\
\text { intermediate } \\
\text { plain }\end{array}$} & $\begin{array}{c}\text { Salak } \\
(\text { Salacca zalacca })\end{array}$ & $\begin{array}{l}\text { Productive, conservation } \\
\text { (fruit) }\end{array}$ & Shaded & Fruit flies \\
\hline & $\begin{array}{c}\text { Beringin } \\
\text { (Ficus benjamina) }\end{array}$ & $\begin{array}{l}\text { ecology (soil water } \\
\text { conservation, air } \\
\text { pollution filter) }\end{array}$ & $\begin{array}{l}\text { partly shaded/full } \\
\text { sun }\end{array}$ & $\begin{array}{l}\text { Insects } \\
\text { (Mosquito, } \\
\text { ants) }\end{array}$ \\
\hline & $\begin{array}{c}\text { Gandaria } \\
\text { (Bouea macrophylla } \\
\text { Griffith) }\end{array}$ & productive, domestic & $\begin{array}{l}\text { Partly shaded/full } \\
\text { sun }\end{array}$ & - \\
\hline & $\begin{array}{c}\text { Kencur } \\
\text { (Kaempferia galanga } \\
\text { L.) }\end{array}$ & Domestic & $\begin{array}{c}\text { Shaded/partly } \\
\text { shaded }\end{array}$ & - \\
\hline & $\begin{array}{l}\text { Picung/keluwek } \\
\text { (Pangium edule) }\end{array}$ & $\begin{array}{l}\text { Domestic, ecology (Soil } \\
\text { water conservation) }\end{array}$ & $\begin{array}{l}\text { Partly shaded/full } \\
\text { sun }\end{array}$ & - \\
\hline \multirow[t]{10}{*}{$\begin{array}{l}\text { Intermediate } \\
\text { plain }\end{array}$} & $\begin{array}{l}\text { Belimbing } \\
\text { (Averrhoa } \\
\text { carambola) }\end{array}$ & Productive & $\begin{array}{c}\text { Shaded/partly } \\
\text { shaded }\end{array}$ & Bats \\
\hline & $\begin{array}{l}\text { Jambu jamaika } \\
\text { (Syzygium } \\
\text { malaccensis) }\end{array}$ & Productive & $\begin{array}{l}\text { Partly shaded/full } \\
\text { sun }\end{array}$ & - \\
\hline & $\begin{array}{c}\text { Jambu Biji } \\
(\text { Psidium guajava })\end{array}$ & Productive & $\begin{array}{l}\text { Partly shaded/full } \\
\text { sun }\end{array}$ & Bats \\
\hline & $\begin{array}{l}\text { Petai Cina } \\
\text { (Leucaena } \\
\text { leucocephala) }\end{array}$ & $\begin{array}{l}\text { Ecology (Wind breaker- } \\
\text { tree morphology) }\end{array}$ & $\begin{array}{l}\text { Partly shaded/full } \\
\text { sun }\end{array}$ & - \\
\hline & $\begin{array}{c}\text { Indian Mango } \\
(\text { Mangifera indica })\end{array}$ & Productive & $\begin{array}{l}\text { Partly shaded/full } \\
\text { sun }\end{array}$ & $\begin{array}{l}\text { Bats } \\
\text { Fruit flies }\end{array}$ \\
\hline & $\begin{array}{c}\text { Kapuk } \\
\text { (Ceiba pentandra L. } \\
\text { Gaertn) }\end{array}$ & $\begin{array}{l}\text { Productive, ecology (Water } \\
\text { and soil protection, } \\
\text { restoration) }\end{array}$ & $\begin{array}{l}\text { Partly shaded/full } \\
\text { sun }\end{array}$ & Bees \\
\hline & $\begin{array}{c}\text { Kecapi } \\
\text { (Sandoricum } \\
\text { koetjape) }\end{array}$ & $\begin{array}{l}\text { Productive, domestic, } \\
\text { ecology (shade) }\end{array}$ & $\begin{array}{l}\text { Partly shaded/full } \\
\text { sun }\end{array}$ & Fruit flies \\
\hline & $\begin{array}{c}\text { Jambu air } \\
\text { (Syzygium aqueum) }\end{array}$ & Productive, domestic & $\begin{array}{l}\text { Partly shaded/full } \\
\text { sun }\end{array}$ & Fruit flies \\
\hline & $\begin{array}{c}\text { Pisang } \\
\text { (Muscaeaei) }\end{array}$ & Productive, domestic & Full sun & Fruit flies \\
\hline & $\begin{array}{c}\text { Talas } \\
\text { (Colocasia esculenta) }\end{array}$ & Domestic & $\begin{array}{l}\text { Partly shaded/full } \\
\text { sun }\end{array}$ & - \\
\hline Intermediate & Bambu & Productive, ecology & Partly shaded/full & Beetle \\
\hline
\end{tabular}


Rini Suryantini, Galavia Permata, Dini Putri Angelia| ASEAN Journal of Community Engagement | Volume 2, Number 2,2018

\begin{tabular}{ccccc}
\hline Zone & Species & Function / Role & Habitat & $\begin{array}{c}\text { Related } \\
\text { Animal/ } \\
\text { Insects }\end{array}$ \\
\hline $\begin{array}{c}\text { plain } \\
\text { and } \\
\text { lowest Plain }\end{array}$ & $\begin{array}{c}\text { Singkong } \\
\text { (Monihot esculenta })\end{array}$ & Productive, domestic & $\begin{array}{c}\text { Partly shaded/full } \\
\text { sun }\end{array}$ & - \\
\cline { 2 - 5 } & $\begin{array}{c}\text { Katuk } \\
\text { (Sauropus } \\
\text { androgynus })\end{array}$ & Domestic & Shaded & - \\
\hline $\begin{array}{c}\text { Highest plain, } \\
\text { intermediate } \\
\text { plain, } \\
\text { lowest Plain }\end{array}$ & $\begin{array}{c}\text { Alang-alang } \\
\text { (Imperata } \\
\text { Cylindrica })\end{array}$ & Ground cover & Full sun & Mosquitos \\
\hline
\end{tabular}

Source: Author, 2018

Native trees, such as kapuk, picung, gandaria, salak, and bamboo are perennials, so they can grow well. According to the locals, some of the trees in the area are more than 50 years old and are considered rarely seen in Condet these days. Gandaria and picung fruits are used for cooking, especially traditional cooking of Betawi and Java, such as rawon and pucung. The natural fibers of kapuk randu can be used for textile base material and filling material of pillow or mattress.

Meanwhile, vegetation found in the intermediate plain produces fruits, such as salak, rambutan, mango, and water apple, that are economically valuable. Because the area can be flooded during rainy days, the trees would only need minimal maintenance. The big trees and bamboos growing nearby can be helpful for bank stabilization in the intermediate plain and low plain of the landscape, and this shows that some native vegetation is present in the floodplain (Gonzales et al., 2015). Bamboos, especially large ones, are used by the locals as construction materials and furniture making. Salak and some shrubs, such as pteridophytes, can grow with minimal sunlight. There is a high volume of insect population, which can contribute to the pollination of fruit plants (Table 1). However, since this area is heavily shaded, some visitors may use this to become a waste disposal area. Presence of waste may result in the presence of mosquitos, which can be disease carriers. 


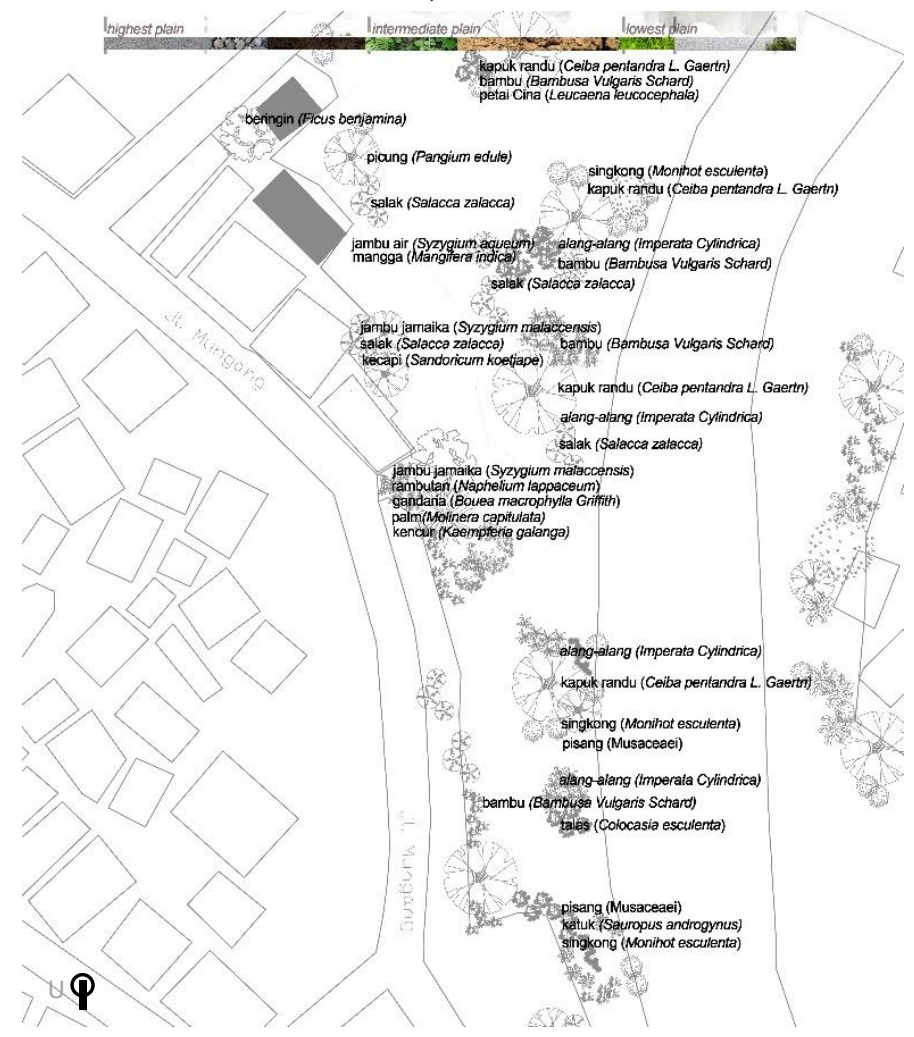

Fig 7. Map of vegetation in Ciliwung Condet

Source: Author, 2018

The lowest part of the area can potentially become an area for a wetland system and sports activities, and other uses including providing the community resources, such as talas, katuk, kapuk randu, and bamboos. There are a lot of bamboos grown at the ridge of the intermediate and low plains to prevent the erosion of the floodplain and to serve as bank stabilizer. However, when high river-flow occurs, and low plain area is flooded, waste materials are trapped in the bamboos, and it becomes waste deposit. The community has to clean the area from the waste deposit and more effort is needed (Somat, 2018). The community has requested the local government for help to overcome the problem, but due to sectoral issues, the problem is not yet solved. The size of the bush and plants including bamboos sometimes limit visual access to the river. This may call for a need for maintenance to keep the bush trimmed. 


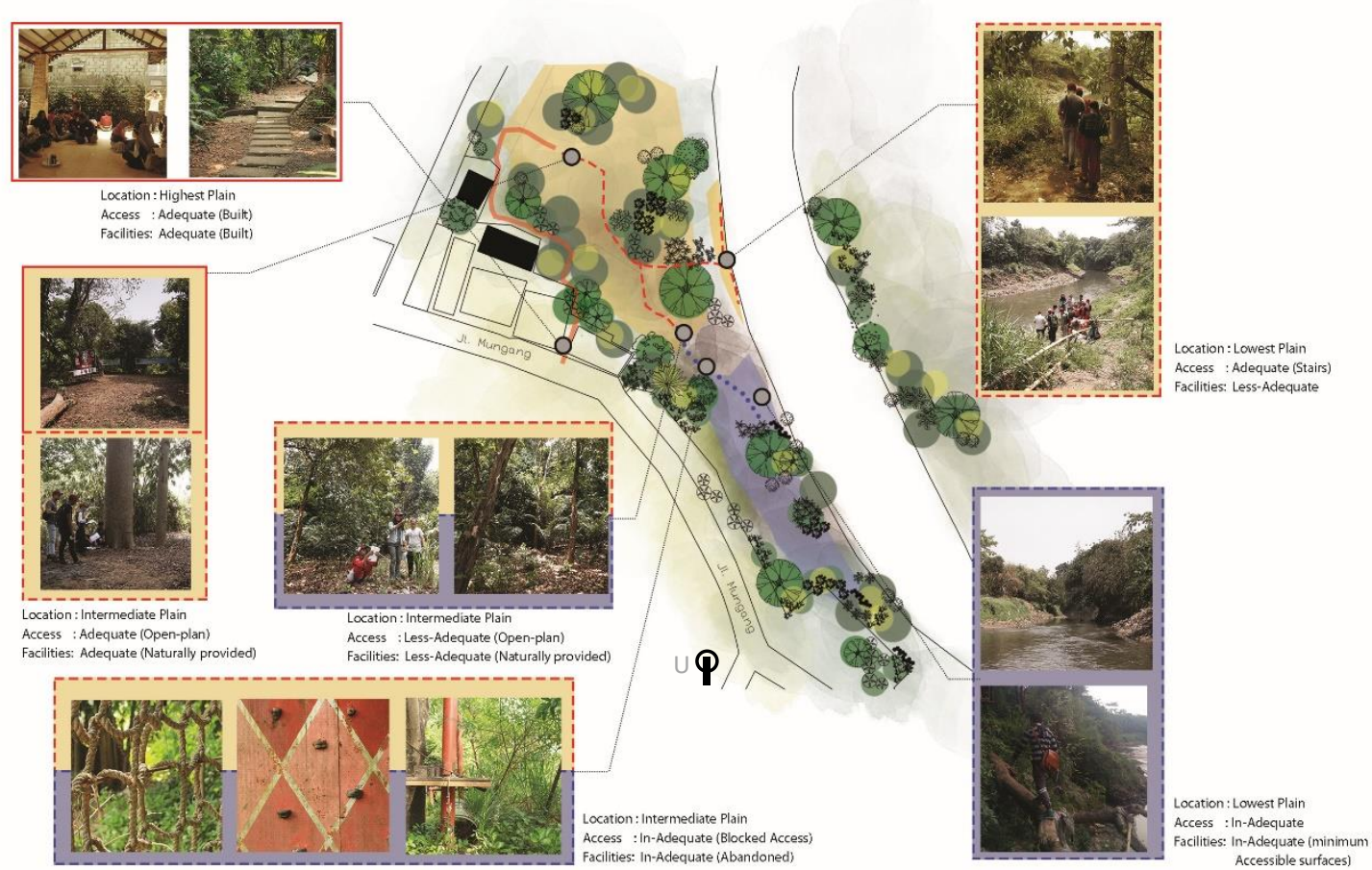

Fig 8. Analysis of connectivity on the landscape

Source: Author, 2018

Based on observation, a knowledge on the ecosystem of the riverside and the activities held there can contribute to the mapping (Fig 8). Activities and facilities are scattered, relatively disconnected, and barely accessible. The mapping analysis indicates that although there are opportunities for educational, recreational and active outdoor activities, the potentials of the vegetation in the area to become benefice have not been explored. Therefore, it is important to maintain a strong connection between activity areas.

\subsection{Connecting ecological scenes}

It is important to integrate the landscape with a holistic program that aims to create environmental improvement that can be enjoyed by all (Public Utilities Board Singapore, 2018). Particularly for Ciliwung river, it is possible to develop the landscape that encourages sustainable lifestyle and activities by and with the waters. A connection is generated through suitable landscape treatment. Developing programs that complement a masterplan is required, especially one in relation to the ecology where the community can learn more about the issues on water and land pollution and how to address them. 
Rini Suryantini, Galavia Permata, Dini Putri Angelia| ASEAN Journal of Community Engagement | Volume 2, Number 2,2018

Based on observation, there are at least two goals for environmental improvement and landscape development in Ciliwung Condet as a green patch, which are necessary to be elaborated in planning the green patch. One is increasing the ecosystem function of the Ciliwung Condet landscape and restoring its native vegetation.

Table 2. Possible landscape treatment

\begin{tabular}{|c|c|c|c|c|}
\hline Zone & $\begin{array}{c}\text { Landscape } \\
\text { Characteristic }\end{array}$ & $\begin{array}{c}\text { Native } \\
\text { Vegetation } \\
\text { Involved } \\
\end{array}$ & Generated Activity & $\begin{array}{l}\text { Landscape } \\
\text { Treatment }\end{array}$ \\
\hline \multirow[t]{2}{*}{ Higher plain } & \multirow[t]{2}{*}{$\begin{array}{l}\text { limited flat } \\
\text { surface, fully } \\
\text { shaded, }\end{array}$} & $\begin{array}{l}\text { beringin, picung, } \\
\text { salak }\end{array}$ & $\begin{array}{l}\text { Ecological purposes: } \\
\text { plant conservation, water } \\
\text { absorption, catchment, } \\
\text { filtration } \\
\end{array}$ & $\begin{array}{l}\text { permeable cover, } \\
\text { retention basin, } \\
\text { bioswale }\end{array}$ \\
\hline & & $\begin{array}{l}\text { beringin, picung, } \\
\text { gandaria, salak, } \\
\text { jambu }\end{array}$ & $\begin{array}{c}\text { Other purposes: } \\
\text { outdoor seating area, } \\
\text { gathering, meeting (passive } \\
\text { activity), fruit production } \\
\text { display }\end{array}$ & $\begin{array}{l}\text { plaza, benches, } \\
\text { stairs, ramps }\end{array}$ \\
\hline \multirow[t]{2}{*}{$\begin{array}{l}\text { Intermedi- } \\
\text { ate plain }\end{array}$} & \multirow[t]{2}{*}{$\begin{array}{l}\text { combination of } \\
\text { steep surface } \\
\text { and large flat } \\
\text { area }\end{array}$} & $\begin{array}{l}\text { petai cina, kapuk } \\
\text { randu, alang- } \\
\text { alang, salak, } \\
\text { bamboo }\end{array}$ & $\begin{array}{c}\text { Ecological purposes: } \\
\text { plant conservation, water } \\
\text { absorption, catchment/ } \\
\text { floodplain, filtration, bank } \\
\text { stabilization } \\
\end{array}$ & $\begin{array}{l}\text { sedimentation } \\
\text { basin, rain garden/ } \\
\text { bioretention, } \\
\text { retention basin, } \\
\text { retention wall }\end{array}$ \\
\hline & & $\begin{array}{l}\text { petai cina, kapuk } \\
\text { randu, jambu, } \\
\text { belimbing, } \\
\text { rambutan, } \\
\text { gandaria, kecapi, } \\
\text { salak }\end{array}$ & $\begin{array}{l}\text { Other purposes: } \\
\text { outdoor activities (sports, } \\
\text { camping, outbound, playing } \\
\text { etc), fruit/ material } \\
\text { production/ display }\end{array}$ & $\begin{array}{c}\text { permeable surface } \\
\text { for plaza, fencing, } \\
\text { treehouse, } \\
\text { outbound facility } \\
\text { (flying fox, wall } \\
\text { climbing, etc), stairs, } \\
\text { ramps }\end{array}$ \\
\hline \multirow[t]{2}{*}{ Lower plain } & \multirow{2}{*}{$\begin{array}{l}\text { narrow } \\
\text { surface, close } \\
\text { to the water } \\
\text { body }\end{array}$} & $\begin{array}{l}\text { kapuk randu, } \\
\text { alang-alang, } \\
\text { talas, bamboo }\end{array}$ & $\begin{array}{l}\text { Ecological purposes: } \\
\text { filtration, buffer, floodplain }\end{array}$ & $\begin{array}{c}\text { wetland } \\
\text { construction }\end{array}$ \\
\hline & & $\begin{array}{l}\text { kapuk randu, } \\
\text { kencur, talas }\end{array}$ & $\begin{array}{c}\text { Other purposes: } \\
\text { outdoor seating area, } \\
\text { gathering, meeting (passive } \\
\text { activity), interaction with } \\
\text { water }\end{array}$ & $\begin{array}{c}\text { walking deck, } \\
\text { benches, retention } \\
\text { wall, stairs, ramps }\end{array}$ \\
\hline
\end{tabular}

Source: Author (2018)

As a watershed area, the masterplan needs to prevent a disconnection between the land and water in term of natural water flow, and to adapt suitable approaches, such as enhancing floodplain as a wetland, capturing stormwater runoff, grading the riverbank with levee breaching and widening, as well as using riparian vegetation along the river to establish river-flow and improvement of river water quality. Activities with specific purposes (ecological purpose, economical purpose, conservation purpose, and recreative purpose) are identified and zones created conceptually based on the native vegetation 
Rini Suryantini, Galavia Permata, Dini Putri Angelia| ASEAN Journal of Community Engagement | Volume 2, Number 2,2018

present, such as kapuk randu and bamboos. Once again, native vegetation plays an important role in this concept. And they will be equipped with a technological technique based on the hydrogeomorphic feature (Table 2 and Fig 9).

a

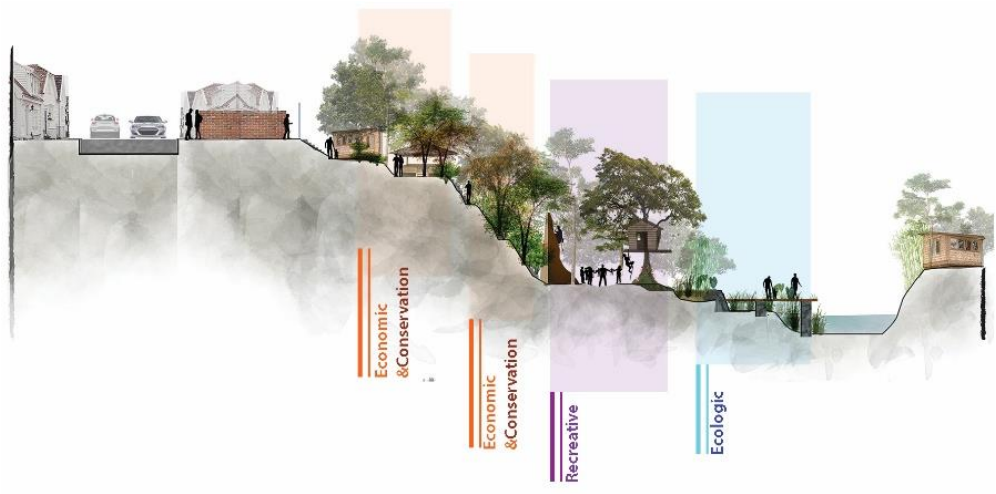

b
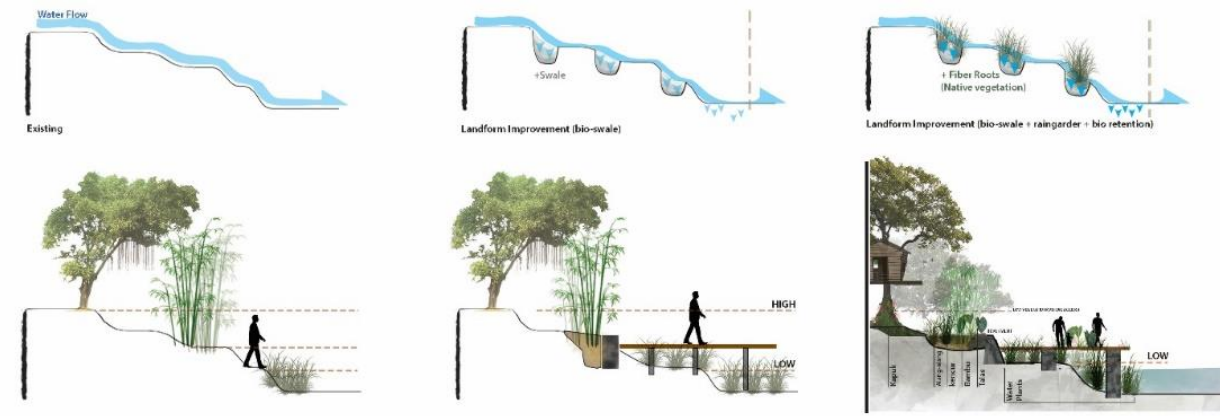

Fig 9. (a) Zoning of activities on the landscape (b) Examples of ecological scenes that displays landscape treatment

Source: Author, 2018

The treatment of the landscape will provide the public an opportunity to learn about the ecosystem and sustainable water management. It is suggested to create scenarios for awareness on ecology through examples of landscape intervention (Table 2). Another recommendation is to put in place a trail or track where community members can do various activities including research, education, and recreation. The landscape is also treated using a similar method that deals with less invasive and rigid hydrologic and geomorphologic condition, emphasizing native vegetation.

\subsection{Ciliwung Condet green patch}

In the new masterplan, adjustments are recommended for the high plain, including improvement of entrance and exit, and sanitation facility, and provision of stairs and 
Rini Suryantini, Galavia Permata, Dini Putri Angelia| ASEAN Journal of Community Engagement | Volume 2, Number 2,2018

ramps. Meanwhile, a pattern of the landscape arrangement is proposed to improve the visual presentation of the connection between the water body and activities areas on the intermediate plain. Native vegetation will be retained and improved with the use of hydrogeomorphic intervention. Salak conservation is suggested; be spread on the shaded area and seating area, as the local fruits are presented. The open ground to be used for active recreational area will also be used as sedimentation basin whenever the river overflows. Tree houses will be constructed on sturdy, large trees as part of the facilities. An inspection will be provided to give way for the growth of wetland vegetation and also to serve as walking deck. This road will connect the green patches, and this may be developed later in time.

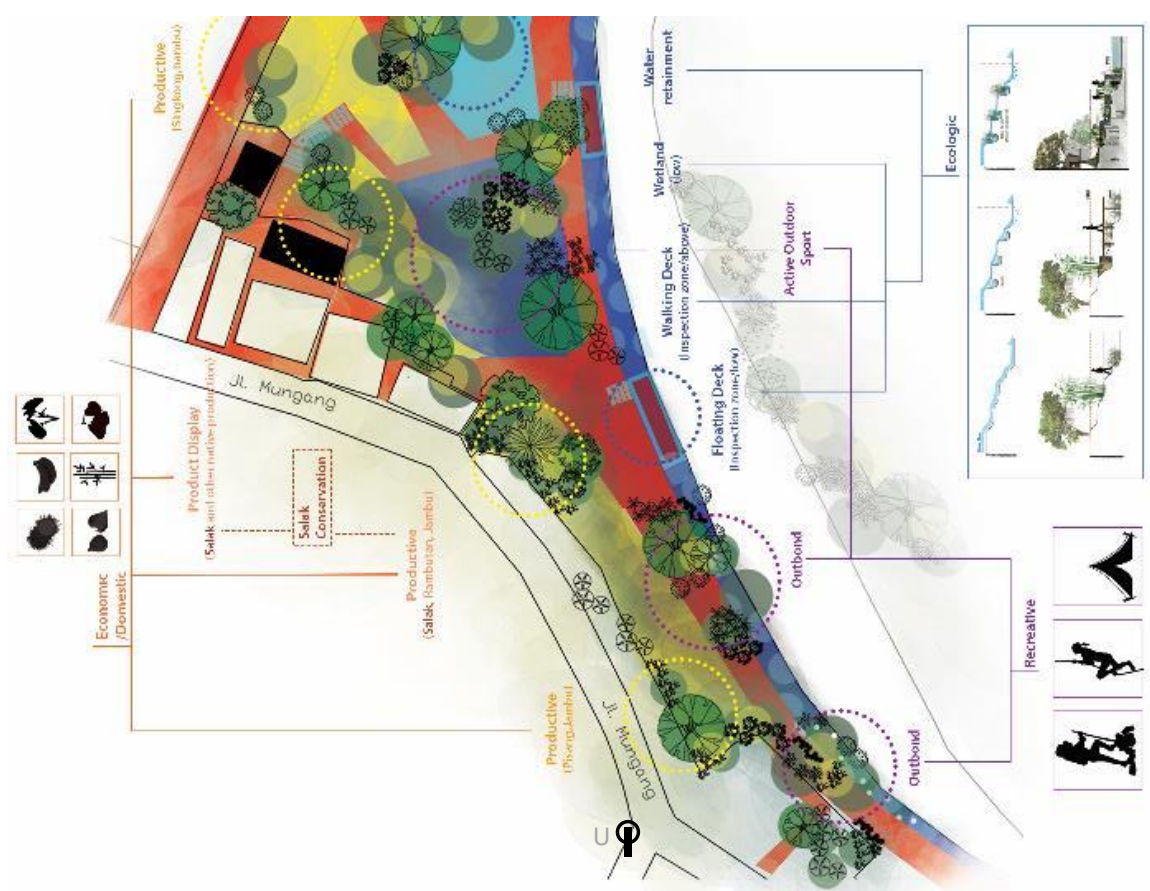

Fig 10. Recommendation of Ciliwung Condet green patch masterplan Source: Author, 2018

The masterplan for the Ciliwung Condet green patch serves as an example of intervention where the nature and people are connected and at the same time the natural feature of the site are respected. After identifying the natural features of the site, the potentials of native vegetation, and the suitable hydrogeomorphic intervention, setting up the zones, and providing the required connectivity, the green patch landscape will be designed to become a place for ecology. The newly structured zones are expected to restore landscape as watershed and also support the activities of the community. 
Rini Suryantini, Galavia Permata, Dini Putri Angelia| ASEAN Journal of Community Engagement | Volume 2, Number 2,2018

Planning the green patch has led to a realization that there is a need for a program that complements the masterplan for the sustainability of the landscape. Developing the masterplan of the green patch through participatory design is the initial step toward the improvement of the whole landscape to become a place for ecology. The challenges for this program are in terms of financial and maintenance means, which are crucial for the masterplan to be implemented. It this is not addressed, the landscape is expected to suffer from recurring floods caused by debris and waste materials, resulting in a threat to the sustainability of the landscape along Ciliwung river. A partnership with local governments and stakeholders may be helpful in gaining support for the development of the green patch along the river, for the sustainability of the urban environment and the wellbeing of the inhabitants.

\section{Conclusion}

In the development of the masterplan for the green patch, principles have been established that will be useful to make it a place for ecology: the community may be encouraged to be involved in the planning activities and a guideline may be developed. Community participation is beneficial to discovering the ecological, sociocultural, or technological aspects of planning. The knowledge of the community will greatly contribute to the knowing and understanding of the site. The knowledge and understanding of the landscape will create the foundation for the design and will generate a masterplan that supports the needs of the community and addresses the local environment issues. A well-planned, well-designed landscape will encourage the public to engage in the sustainability of the environment and lead to awareness in relation to ecology.

The landscape should have its own personality for it to establish a connection between the nature and people. It should be perceived comprehensively, which often disregarded during the planning process, but at the same time looking at the activities of the community at the site. Landscape as place for ecology is rarely highlighted, and therefore important to be raised in accordance with the aim of the community. Native flora or fauna can be a factor that contributes to the uniqueness of the landscape, and eventually guides the design and open ideas for a new development procedure. 


\section{Acknowledgments}

This community engagement project is funded by the Directorate for Research and Community Engagement (Direktorat Riset dan Pengabdian Masyarakat) Universitas Indonesia 2018. The project is conducted together with Komunitas Ciliwung Condet (KCC) led by M Abdulkadir, along with Abdul Somat and Sudirman Asun. This project is developed together with the lecturers, students, and graduates of architecture and civil engineering from Universitas Indonesia. Thanks especially to Herlily, Dwinanti Rika M., Bayu Priyo Laksono, Farkhan Amriel, Ritami, Syaiful Rachman, and M. Aariq Nurfidani, for the active engagement in developing modules for mapping and participatory mapping.

\section{References}

Abd El Aziz, N. A. (2016). Water sensitive landscape, case study: Public open green spaces in Naser City, Egypt. Journal of Landscape Ecology.

Abdulkadir, M. (2018, July 25). Diskusi awal. (T. P., 2018, Interviewer)

Asun, S. (2018). (Rini, Interviewer)

Farr, D. (2008). Sustainable Urbanism - Urban Design with Nature. New Jersey: John Wiley \& Sons.

Fletcher, T. D., \& et. al. (2015). SUDS, LID, BMPs, WSUD and more - The evolution and application of terminology. Urban Water Journal, 525-542.

Gonzales, E., Sher, A. A., Tabacchi, E., Masip, A., \& Poulin, M. (2015). Restoration of riparian vegetation: A global review of implementation and evaluation approaches in the international, peer-reviewed literature. Journal of Environmental Management, 85-94.

Herrington, S. (2017). Landscape Theory in Design. New York: Rooutledge.

Hester, R. T. (2006). Design for Ecological Democracy. Cambrige: MIT Press.

Kondolf, G., Boulton, A., O'Daniel, S., \& Poole, G. (2006). Process-based ecological river restoration: Visualizing three-dimensional connectivity and dynamic vectors to recover lost linkages. Ecology and Society.

Livesey, G. (2015). Towards an ecology of the palladian villa. In M. Neveu, \& N. Djavaherian, Architecture's Appeal - How theory informs architectural praxis (pp. 228-239). Oxon: Routledge.

Motloch, J. L. (2000). Introduction to Landscape Design . New Jersey: Wiley. 
Rini Suryantini, Galavia Permata, Dini Putri Angelia| ASEAN Journal of Community Engagement | Volume 2, Number 2, 2018

Padawangi, R., \& Douglass, M. (2015). Water, water everywhere: Toward participatory solutions to chronic urban flooding in Jakarta. Pacific Affairs, 88(3), 517-550.

Palmer, M., Allan, J., Lake, P., \& Alexander, G. (2005). Standards for ecologically successful river restoration. Journal of Applied Ecology, 42, 208-217.

Public Utilities Board Singapore. (2018). Active, Beautiful, Clean Water Design Guidelines. Singapore: PUB.

Sinha, S. (2012). Architecture for Rapid Change and Scarce Resources. Oxon: Routledge.

Tampi, D. M., Sumabrata, J., \& Darmajanti, L. (2018). Environmental lovers group: a networking of Ciliwung Depok Community. Proceeding from the Friendly City 4 From Research to Implementation For Better Sustainability. IOP Conference Series: Earth and Environmental Science, 126.

Warner, C. (2015). Participatory Mapping: a literature review of community-based research and participatory planning. 